\title{
生物群最適化に基づくシリアルリンクロボットの跳躍高最大化
}

\author{
松 井猛*1 加 藤 浩 介*1 坂 和 正 敏*1 \\ 宇 野 剛 史*1 東 森 充*2 金子 真*2

\section{Maximization of Jump Height of a Serial Link Robot Based on Particle Swarm Optimization}

\author{
Takeshi Matsui*1, Kosuke Kato*1, Masatoshi Sakawa*1, \\ Takeshi Uno*1, Mitsuru Higashimori*2 and Makoto Kaneko*2
}

\begin{abstract}
In this paper, we focus on the maximization of the jump height of a serial link robot. The jump height maximization problem is formulated as a nonlinear programming problem, where torque patterns to drive joints in the robot are decision variables and the objective function is an inexplicit function whose value is obtained as an output of a jump simulator. As a previous reasearch, an approximate solution method using a genetic algorithm was proposed for the jump height maximization problem. In the research, some interesting joint drive torque patterns were found by the method, but it costed much time to obtain a drive torque pattern. In order to improve the accuracy of the obtained solution and shorten the computational time, in this paper, we propose a new solution method based on particle swarm optimization (PSO).
\end{abstract}

Key Words: Serial Link Robot, Jump Height Maximization, Nonlinear Programming, Particle Swarm Optimization

\section{1. は じめに}

今日, 科学技術の発展に伴い, ロボットの研究開発が進めら れ, 広く利用されてきている. 特に, 脚式歩行ロボットは様々 な路面状況において移動可能であり, 利便性が高い。これまで の脚式歩行ロボットに関する研究は, 脚先端で構成される支持 多角形内にロボットの重心を確保することを前提とした静的な 歩行に関する研究と, 支持多角形から重心が外れることを許容 した動的歩行に関する研究というように，大きく二つに分類す ることができる [1]. 後者に分類される跳躍ロボットは, 段差の ある路面を移動可能であり, 研究が盛んに行われている. 跳躍 を行うロボットの制御は, ロボティクスや非線形制御論, その 中でもハイブリッドシステム論の立場から見て極めて興味深い 研究課題である. 多くの動的歩行ロボットにおいて, 脚制御の ためにバネや空圧アクチュエータなどが用いられるが, これら は一般に器用さに欠けるという問題点がある。この問題点を解 決するため, 東森ら [2] は, 脚制御に回転型モータを利用したシ リアルリンクロボットに焦点を当てている。シリアルリンクロ ボットに関しては, 森本ら [3] [4]により, 強化学習を用いたシ

原稿受付 2006 年 12 月 28 日

*1 広島大学大学院工学研究科

$* 2$ 大阪大学大学院工学研究科

${ }^{* 1}$ Graduate School of Engineering, Hiroshima University

${ }^{* 2}$ Graduate School of Engineering, Osaka University

口本論文は有用性で評価されました。
リアルリンクロボットによる起きあがり動作の獲得が議論され ている。森本らの研究は与えられたロボット仕様に対する効果 的な強化学習手法に議論の重点を置いているのに対し, 東森ら は,トルク制限, 関節可動制限を与えた上で最大跳躍を実現す るのにどのようなトルクパターンを生成し, どのような跳躍パ ターンが現れるのか, さらにそれらがトルク制限, 関節可動制 限に対してどう変わっていくのかという点に注目している.そ して, シリアルリンクロボットの跳躍高を最大化する駆動トル ク波形を求める問題を非線形計画問題として定式化するととも に，遺伝的アルゴリズム（GA）を適用して，その問題に対す る近似最適解を求め, 興味深い跳躍パターンが得られることを 示している. しかしながら, GA に基づく求解は, 局所的探索 が難しい, 個体の評価（シミュレータを使用）に時間がかかる ため多大な計算時間が必要となる, などの問題点がある.また, 彼らは, 求解の際, 駆動トルク波形を連続波形ではなく等間隔 でサンプリングした時系列として取り扱っているため, 探索空 間が高次元となり, 多大な計算時間が必要となる一因となって いる.

このような状況の下で, 本研究では, 東森ら [2] が考察してい るシリアルリンクロボットの跳躍高最大化問題をとりあげ，駆動 トルク波形の表現を工夫することにより探索空間を低次元化す るとともに, 近年, 非線形計画問題の近似解法として注目されて きている生物群最適化 (PSO : Particle Swarm Optimization) に基づく解法を提案し，求解の高速化および高精度化を目指す. 


\section{2. シリアルリンクロボットの跳躍高最大化問題}

本研究では, Fig. 1 に示されるような，直列に接続された $N$ 個のリンクとその関節部に $N-1$ 個の駆動モータをもつシリ アルリンクロボットを考察の対象とする。ここで, $m_{i}, I_{i}, l_{i}$, $i=1,2, \ldots, N$ はそれぞれ第 $i$ リンクの質量, 慣性モーメント および長さを表し, $\tau_{j}, j=1,2, \ldots, N-1$ は第 $j$ 関節に対し て時刻 $t=0$ から $t=T$ までの間に与えられる駆動卜ルク波 形を表す。すなわち，第 $j$ 関節に対する駆動卜ルク波形 $\tau_{j}$ は， 時刻 $t$ における第 $j$ 関節に対する駆動トルクを $\tau_{j}(t)$ を用いて, $\tau_{j}=\left\{\tau_{j}(t) \mid 0 \leq t \leq T\right\}$ のように表される.また，第 $j$ 関 節の駆動トルクを供給するモータは，モータ本体は第 $j$ リンク に固定されるがモー夕回転軸は第 $j+1$ リンクに固定されるも のとする．簡単のため，モータ質量はリンク質量に含まれ，各 リンクの重心はリンク中心に位置するものとする．通常の DC サーボモー夕は角速度に応じたトルクの減少特性をもつのに対 して，AC サーボモータでは速度に応じて電流供給量を増加さ せることによりトルク出力を維持することが可能なものが存在 するため, 本研究では, このような $\mathrm{AC}$ サーボモー夕の使用を 仮定する。このモータの角速度の限界值を $\omega_{\max }$ とする.

本研究では, 文献 [2] と同様に, Fig. 1 に示すようなシリアル リンクロボットにどのような関節駆動トルクを与えれば跳躍高 が最大になるかに注目する，文献 [2]に述べられているように， 求める関節駆動卜ルクは次のように定式化される跳踓高最大化 問題の最適解として与えられる。

$$
\left.\begin{array}{ccc}
\operatorname{maximize} & h_{\max }\left(\tau_{1}, \tau_{2}, \ldots, \tau_{N-1}\right) & \\
\text { subject to } & \tau_{1, \min } \leq \tau_{1}(t) \leq \tau_{1, \max }, 0 \leq t \leq T \\
& \tau_{2, \min } \leq \tau_{2}(t) \leq \tau_{2, \max }, 0 \leq t \leq T \\
\vdots & \\
& \tau_{N-1, \min } \leq \tau_{N-1}(t) \leq \tau_{N-1, \max }, 0 \leq t \leq T
\end{array}\right\}
$$

ここで, $\tau_{j, \min }$ と $\tau_{j, \max }$ はそれぞれ第 $j$ 関節に対する駆動

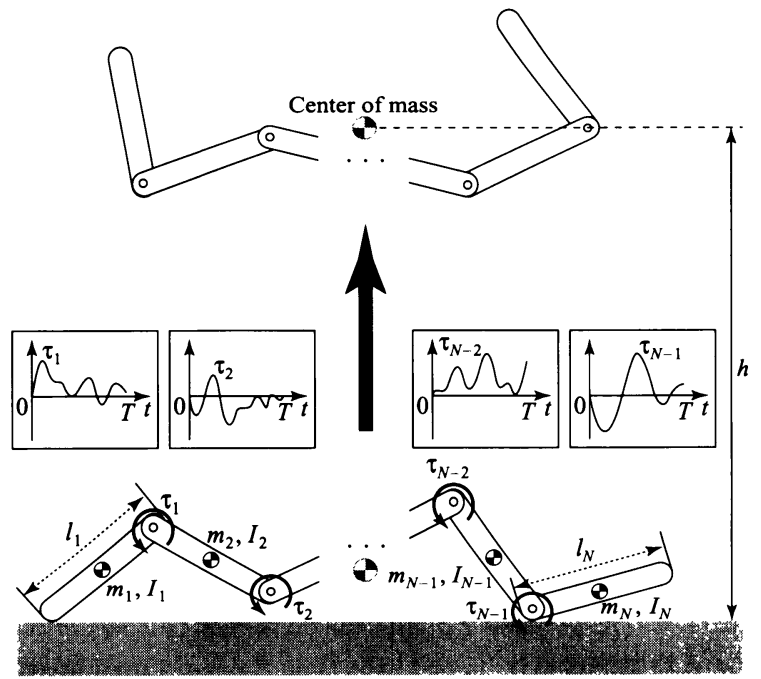

Fig. 1 The model of a serial link robot
トルクの下限および上限を表す。また，目的関数 $h_{\max }\left(\tau_{1}\right.$, $\left.\tau_{2}, \ldots, \tau_{N-1}\right)$ は各関節に対して $\tau_{1}, \tau_{2}, \ldots, \tau_{N-1}$ という駆動 トルク波形が与えられたときのシリアルリンクロボットの跳躍 高, すなわち, 跳躍動作に扔ける最高重心到達点の高さを表す. したがって, 問題は跳躍高 $h_{\max }$ を最大にする駆動トルク波形 $\tau_{1}, \tau_{2}, \ldots, \tau_{N-1}$ を求めるというものであるが，与えられた駆動 トルク波形 $\tau_{1}, \tau_{2}, \ldots, \tau_{N-1}$ に対するシリアルリンクロボット の動作は複雑であり，駆動卜ルク波形と跳躍高との対応は非線形 となるとともにそれを数学的に陽に表現することも不可能である ため, 東森ら [2] は, 物体間の接触には, 接触している 2 物体の 間に仮想的なバネ・ダンパを考え，それによって接触力が発生す るという一般的なバネ・ダンパモデルを採用し，ダイナミックシ ミュレーションソフト ADAMS (Mechanical Dynamic Inc.) を使用して与えれらた駆動トルク波形に対するシリアルリンク ロボットの動作をシミュレートし，その跳躍高を求めている。し かしながら，このような陽に表現されない目的関数をもつ最適 化問題に対して, 伝統的な数理計画手法の適用による求解は困 難である。 そこで, 東森ら [2] は, 遺伝的アルゴリズムを用いた 解法を提案し, 問題 (1) の近似最適解を求め, 興味深い跳躍パ ターンが得られることを示している。しかしながら，GAに基 づく求解は, 局所的探索が難しい, 個体の評価（シミュレータ を使用）に時間がかかるため多大な計算時間が必要となる，な どの問題点がある.これに対して, 生物群最適化手法は局所的 探索能力が比較的高いとともに一般にGA よりも少ない個体で 探索が可能であるため, 生物群最適化手法の使用により計算時 間の改善が期待される。 また, 東森ら [2] は, 求解の際, 駆動 トルク波形を連続波形ではなく等間隔でサンプリングした時系 列として取り扱っているため，探索空間が高次元となっている. 具体的には，文献 [2] の数值実験において，4関節に対する駆 動トルク波形を 200 点でサンプリングした時系列としているた め, 探索空間は 800 次元となっており, 多大な計算時間が必要 となる一因となっている.

このような状況の下で, 本研究では, 探索空間の低次元化と 生物群最適化（PSO：Particle Swarm Optimization）に基つ” く解法の提案により, 求解の高速化および高精度化を目指す。

\section{3. 探 索 空 間}

文献 [2] の数値実験において, 得られている近似最適解（近 似最適駆動トルク波形）は，ある期間はトルクの上限值 $\tau_{j, \max }$ をとり, 次の期間は下限值 $\tau_{j, \min }$ をとり，その次の期間は 0 の 值をとる，というような矩形波を重ね合わせたような形をして いるとともにその值の変化の頻度はあまり大きくない．この特 徵に注目し, 探索空間の低次元化のために, 駆動卜ルク波形を Walsh 級数 [5]により表現される関数に制限する。具体的には, Fig. 2 のような Paley 順序 [5] で順序付けられた 7 次までの Walsh 直交関数 $\psi_{0}(\cdot), \psi_{1}(\cdot), \ldots, \psi_{7}(\cdot)$ を用いて次のように表 現される関数に制限する。

$$
\tau_{j}(t)=\sum_{k=0}^{7} w_{k}^{j} \psi_{k}(t), \quad 0 \leq t \leq T
$$

このとき, $\boldsymbol{w}^{j}=\left(w_{0}^{j}, w_{1}^{j}, \ldots, w_{7}^{j}\right)$ とすると $\left(\boldsymbol{w}^{1}, \boldsymbol{w}^{2}, \ldots, \boldsymbol{w}^{N-1}\right)$ 

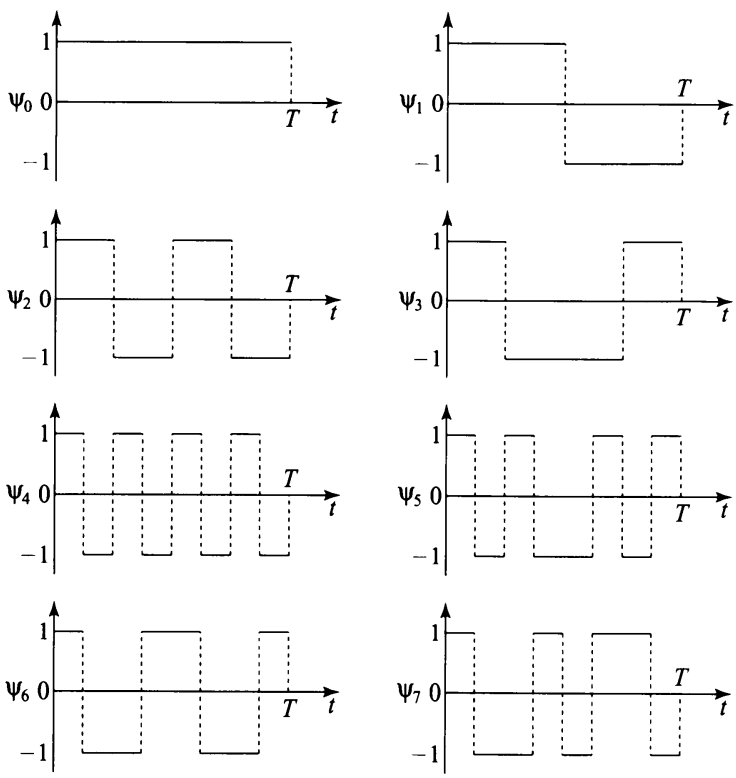

Fig. 2 Paley ordered Walsh functions

$\in R^{8(N-1)}$ が決定変数ベクトルとなり, 跳躍高最大化問題 $(1)$ は次のように書き換えられる。

$$
\left.\begin{array}{rl}
\operatorname{maximize} & f(\boldsymbol{w})=h_{\max }\left(\boldsymbol{w}^{1}, \boldsymbol{w}^{2}, \ldots, \boldsymbol{w}^{N-1}\right) \\
\text { subject to } & \tau_{j, \min } \leq \tau_{j}(t)=\sum_{k=0}^{7} w_{k}^{j} \psi_{k}(t) \leq \tau_{j, \max }, \\
0 \leq t \leq T, j=1,2, \ldots, N-1 \\
\\
\boldsymbol{w}=\left(\boldsymbol{w}^{1}, \boldsymbol{w}^{2}, \ldots, \boldsymbol{w}^{N-1}\right) \in R^{8(N-1)}
\end{array}\right\}
$$

いま, $n=8(N-1), \boldsymbol{x}=\boldsymbol{w}, g_{2 j-1}(\boldsymbol{w})=-\sum_{k=0}^{7} w_{k}^{j} \psi_{k}(t)+$ $\tau_{j, \min }, g_{2 j}(\boldsymbol{w})=\sum_{k=0}^{7} w_{k}^{j} \psi_{k}(t)-\tau_{j, \max }, j=1,2, \ldots, N-1$ とすると, 問題 (3) は次のように表される.

$$
\left.\begin{array}{rl}
\operatorname{maximize} & f(\boldsymbol{w}) \\
\text { subject to } & g_{i}(\boldsymbol{w}) \leq 0, \quad i=1,2, \ldots, 2(N-1) \\
& \boldsymbol{w} \in R^{8(N-1)}
\end{array}\right\}
$$

ここで, 問題 (4) の実行可能領域を $X$ とする. 以下では, こ の問題に対する生物群最適化（PSO）に基づく解法を提案する.

\section{4. 生物群最適化（PSO）に基づく解法}

生物群最適化（PSO：Particle Swarm Optimization）手法 は Kennedy ら[6]により提案された最適化手法で，鳥の群れ や魚の群れにおける個体は自身の情報だけでなく群れの情報も 用いて行動していることに注目し，各個体が現在の進行方向と 群れの中の最良点への方向を考慮して, 次の進行方向を決定す ることにより，群れを成しながら集団としてよりよい点を探す ように振る舞うという点を模擬した探索手法である.

Kennedy ら [6] によって提案されたPSO 手法では, 個体群 の中の個体は Fig. 3 に示されるように移動し, その探索方向と 探索点の更新式は次のように定義される.

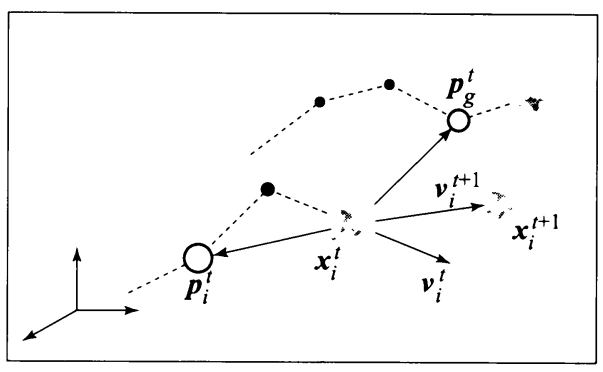

Fig.3 Movement of an individual

$$
\begin{gathered}
\boldsymbol{v}_{i}^{t+1}=\omega^{t} \boldsymbol{v}_{i}^{t}+c_{1} R_{1}^{t}\left(\boldsymbol{p}_{i}^{t}-\boldsymbol{x}_{i}^{t}\right)+c_{2} R_{2}^{t}\left(\boldsymbol{p}_{g}^{t}-\boldsymbol{x}_{i}^{t}\right) \\
\boldsymbol{x}_{i}^{t+1}=\boldsymbol{x}_{i}^{t}+\boldsymbol{v}_{i}^{t+1}
\end{gathered}
$$

ここで, $\boldsymbol{x}_{i}^{t}$ は個体 $i$ の $t$ 回目の探索点, $\boldsymbol{p}_{i}^{t}$ は個体 $i$ の過去 の探索における最良の目的関数値を与える探索点, $\boldsymbol{p}_{g}^{t}$ は $\boldsymbol{p}_{i}^{t}$, $i=1, \ldots, I$ の中の最良の探索点，すなわち，個体群全体の過去 の探索における最良の探索点であり， $R_{1}^{t}, R_{2}^{t}, c_{1}, c_{2}, \omega^{t}$ は パラメータである。

個体 $i$ は, 現在の探索方向 $\boldsymbol{v}_{i}^{t}$, 現在の探索点 $\boldsymbol{x}_{i}^{t}$ からその個 体自身の最良探索点 $\boldsymbol{p}_{i}^{t}$ へ向かう方向および現在の探索点 $\boldsymbol{x}_{i}^{t}$ か ら個体群の最良探索点 $\boldsymbol{p}_{g}^{t}$ へ向かう方向，という三つの方向を 用いて次の探索方向 $\boldsymbol{v}_{i}^{t+1}$ を決定し, 現在の探索点 $\boldsymbol{x}_{i}^{t}$ から次 の探索点 $\boldsymbol{x}_{i}^{t+1}$ へ移動する.

上記のような原理に基づいて動作する PSO における個体は, 自分自身の過去の情報と群れの情報を有効に利用して自身の利 益を最大にするように行動するとともに，自身の情報と群れの 情報を次々更新することにより，群れを成しながら集団として よりよい点を探すように振る舞うため, PSO は高い探索能力が 期待できるとともに簡単な移動式により実現できることから高 速に実行可能であるという特徵をもつ. しかし, Kennedy らの 基本的な PSO 手法では，基本的に決定変数に対する上下限制 約以外の制約条件をもつ問題に対しては直接適用できないとい う問題点があるとともに，探索の後半において個体が個体群の 最良探索点付近に集まってくるため局所的最適解に停留しやす いという問題点がある.そこで，筆者ら [7]は，これらの問題 点に対して, 初期個体群の生成方法, 個体の移動方法および評 価関数を変更することにより，制約条件を考慮した探索を可能 とするとともに，局所的最適解に停留することなく大域的な探 索が可能となるような改良型 PSO 手法を提案し, その有用性 を示した，そこで, 本研究では, 跳躍高最大化問題 (3) に対す る改良型 PSO 手法に基づく解法を提案する.

\section{1 個体の初期探索点の生成}

Kennedy らの基本的な PSO 手法は, 各決定変数に対する 上下限制約以外の制約をもたない非線形計画問題を対象として いるので, 個体の初期探索点の生成において，それぞれの変数 の上下限制約を満たす領域内にランダムに生成することにより, 実行可能な初期探索点の生成が可能であった。しかし, 跳躍高 最大化問題（3）は上下限以外の制約をもつ一般の非線形計画問 題であるため, 初期の探索点をそれぞれの変数の上下限制約内 にランダムに生成するという従来の PSO 手法の初期探索点の 生成法では，すべての探索点が制約領域内に生成されるとは限 


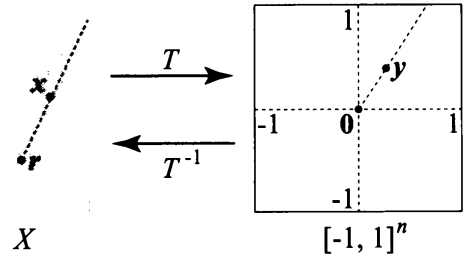

Fig. 4 A homomorphous mapping

らないため, 探索効率が低下する可能性がある，そこで，すべ ての初期探索点を実行可能とするために, Koziel ら [8]によっ て提案された準同型写像を採用する.

Koziel ら [8] は実行可能領域 $X$ から $n$ 次元超立方体 $[-1,1]^{n}$ への次のような性質をもつ写像 $T$ を考察している (Fig. 4).

(1) 適当な $X$ の点 $\boldsymbol{r}$ に対して $n$ 次元超立方体 $[-1,1]^{n}$ の中 心である原点 0 を対応させる。

$$
T: \boldsymbol{r} \mapsto \mathbf{0}
$$

（2）任意の $\boldsymbol{x} \in X$ に対して, $\boldsymbol{r}+(\boldsymbol{x}-\boldsymbol{r}) \cdot t$ が $X$ の境界とな る正の実数 $t$ を $t_{\max }$ とするとき, 次のような $n$ 次元超立 方体 $[-1,1]^{n}$ の点 $\boldsymbol{y}$ に対応させる,

$$
T: \boldsymbol{x} \mapsto \boldsymbol{y}:=\frac{\boldsymbol{x}-\boldsymbol{r}}{t_{\max } \cdot \max _{j=1, \ldots, n}\left(x_{j}-r_{j}\right)}
$$

本研究では, $n$ 次元超立方体 $[-1,1]^{n}$ 内にランダムに $I$ 個 の点を生成した後, これらの点を Koziel ら [8]によって提案さ れた準同型写像 $T$ の逆写像 $T^{-1}$ を用いて写像すると実行可能 領域内の点にうつされるので，これらの点を個体の初期探索点 とする、ただし, 準同型写像を用いるためには, 超立方体の原 点に対応する一つの実行可能解 (基点解) $\boldsymbol{r}$ を求めておく必要 がある。そこで，まず次のような制約違反に基づいて定義され る関数

$$
G(\boldsymbol{x})=\exp \left[-\theta \sum_{j=1}^{2(N-1)} R\left(\frac{g_{j}(\boldsymbol{x})}{\bar{g}_{j}}\right)\right]
$$

を目的関数とする最大化問題

$$
\left.\begin{array}{rl}
\operatorname{maximize} & G(\boldsymbol{x}) \\
\text { subject to } & l_{j} \leq x_{j} \leq u_{j}, j=1, \ldots, n
\end{array}\right\}
$$

を解く.ここで, $\bar{g}_{j}, j=1, \ldots, 2(N-1)$ は各制約式の制約違 反をスケーリングするためのパラメータであり，

$$
R(\xi)= \begin{cases}\xi, & \xi \geq 0 \\ 0, & \xi<0\end{cases}
$$

で, $\theta$ は正の定数である.この問題は上下限制約だけを含む問 題であるので, 従来の PSO 手法が適用可能であるが, ある定 められた回数適用しても実行可能解が得られないときは，もと の問題には実行可能解が存在しないものと判断することになる.

\section{2 制約の取り扱い}

本研究では, PSO 手法における制約を考慮した探索のため に，探索点が実行不可能な個体を 2 分法により実行可能となる
宇野剛史東森充金子真

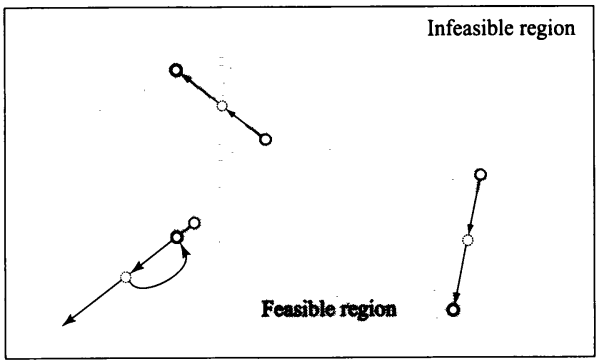

Fig. 5 Modification of individuals by the bisection method

ように修正する方法を採用する。ただし，2 分法の実行には時 間がかかるため，2 分法による個体修正を行う部分個体群と実 行不可能領域への移動を許可する部分個体群という二つの部分 個体群を用いる PSO 手法を提案する。

4.2 .12 分法による個体修正を行う部分個体群

探索空間を上下限制約を満たす領域 $U$ とし, 個体 $i$ の次の 探索点 $\boldsymbol{x}_{i}^{t+1}$ が実行不可能であるとき，まず，修正探索点の候 補を $\boldsymbol{\alpha}_{i}^{t+1}(p)=\boldsymbol{x}_{i}^{t+1}+2^{p} \cdot \boldsymbol{v}_{i}^{t+1}, p=1,2, \ldots, p_{\max } \quad\left(p_{\max }\right.$ は設定された自然数）とする.もし $\left\{p \mid \boldsymbol{\alpha}_{i}^{t+1}(p) \in X, p=\right.$ $\left.1,2, \ldots, p_{\max }\right\} \neq \emptyset$ ならば, $P=\min \left\{p \mid \boldsymbol{\alpha}_{i}^{t+1}(p) \in X, p=\right.$ $\left.1,2, \ldots, p_{\max }\right\}$ として $\boldsymbol{\alpha}_{i}^{t+1}(P)$ を修正探索点とする. 次に, も し $\left\{p \mid \boldsymbol{\alpha}_{i}^{t+1}(p) \in X, p=1,2, \ldots, p_{\max }\right\}=\emptyset$ ならば, 修正探 索点の候補を $\boldsymbol{\beta}_{i}^{t+1}(p)=\boldsymbol{x}_{i}^{t}+2^{-p} \cdot \boldsymbol{v}_{i}^{t+1}, p=1,2, \ldots, p_{\max }$ とする.もし $\left\{p \mid \boldsymbol{\beta}_{i}^{t+1}(p) \in X, p=1,2, \ldots, p_{\max }\right\} \neq \emptyset$ な らば, $P=\min \left\{p \mid \boldsymbol{\beta}_{i}^{t+1}(p) \in X, p=1,2, \ldots, p_{\max }\right\}$ とし て $\boldsymbol{\beta}_{i}^{t+1}(P)$ を修正探索点とする. もし $\left\{p \mid \boldsymbol{\beta}_{i}^{t+1}(p) \in X, p=\right.$ $\left.1,2, \ldots, p_{\max }\right\}=\emptyset$ ならば, $\boldsymbol{x}_{i}^{t}$ を修正探索点とする.

このような操作により，すべての個体の探索点を実行可能と することができる(Fig.5).

\section{2 .2 実行不可能領域への移動を許可する方法}

2 分法による個体修正を行う場合には, 制約式を何回も計算 する必要があり, 問題が大規模になると多くの計算時間が必要 となる、また, 大域的最適解を含む実行可能領域の形状（例え ば，その領域が極端に小さい，実行不可能領域に囲まれている 等）により探索が偏るという問題点があった. そこで, 個体の移 動において実行不可能領域への移動を許可することにより, 計 算時間の短縮と探索領域の広域化を目指す。

\section{3 個体の状況に合わせた移動}

上述の PSO 手法の探索方向の更新式（5）は常に個体群の最 良探索点への方向を含んでいるため, 個体の状況によっては次 の探索点への移動で個体群の最良探索点付近に集中し，探索が 偏りやすくなる場合があると考えられる。 よって, 個体の現在 の状況を適切に判断し, 次の探索点への移動の方法を個体の状 況に合わせて変更することによりこれらの問題に対処する.

4.3.1 直前で個体自身の最良探索点が更新された場合

いま, 個体 $i$ の現在の探索点 $\boldsymbol{x}_{i}^{t}$ からの移動を考える. Fig. 6 のように, 直前の探索点 $\boldsymbol{x}_{i}^{t-1}$ がその個体の最良探索点 $\boldsymbol{p}_{i}^{t}$ で あるとき, 現在の移動方向 $\boldsymbol{v}_{i}^{t}$ とその個体の最良探索点 $\boldsymbol{p}_{i}^{t}$ への 方向が正反対になって打ち消し合うため, 次の探索点 $\boldsymbol{x}_{i}^{t+1}$ は 個体群の最良探索点 $\boldsymbol{p}_{g}^{t}$ 付近の点となる可能性が高くなり, 個 体が個体群の最良探索点 $\boldsymbol{p}_{g}^{t}$ へ集中しやすくなる.そこで，こ 


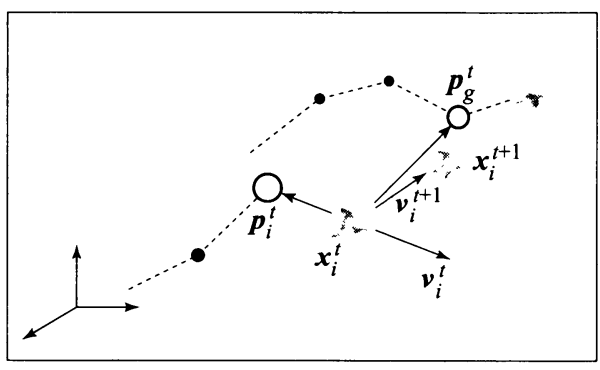

Fig. 6 The search direction when the best search point of an individual is renewed at the previous search point

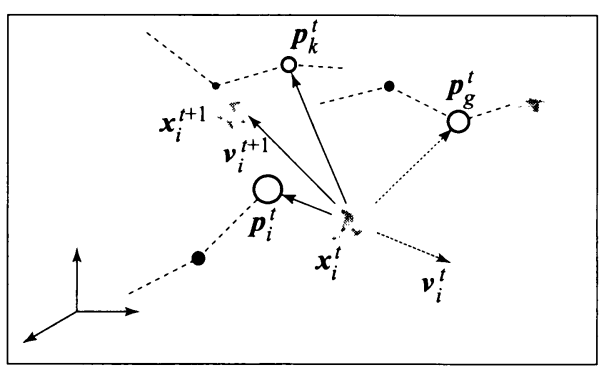

Fig. 7 The new search direction when the best search point of an individual is renewed at the previous search point

のような場合には，次の探索方向 $\boldsymbol{v}_{i}^{t+1}$ を次の式（11）により 決定するように変更する (Fig. 7).

$$
\boldsymbol{v}_{i}^{t+1}=c_{1} R_{1}^{t}\left(\boldsymbol{p}_{i}^{t}-\boldsymbol{x}_{i}^{t}\right)+c_{2} R_{2}^{t}\left(\boldsymbol{p}_{k}^{t}-\boldsymbol{x}_{i}^{t}\right)
$$

ここで, $\boldsymbol{p}_{k}^{t}$ はランダムに選択された個体 $k$ の最良探索点である.

この変更により, 個体群が探索領域内に大きく散らばってい る探索の初期の段階では, 個体が個体群の最良探索点 $\boldsymbol{p}_{g}^{t}$ 付近 に移動せずに様々な方向へ移動することになるので, 個体群の 最良探索点 $\boldsymbol{p}_{g}^{t}$ 一集中し，探索が偏ることを緩和している，一 方, 探索の後期の段階では, パラメータ $\omega^{t}$ の值の隇少や個体 の他の状況での移動により, 個体はしだいに個体群の最良探索 点 $\boldsymbol{p}_{g}^{t}$ へ集中していく. よって, ランダムに個体 $k$ を選び, そ の最良探索点 $\boldsymbol{p}_{k}^{t}$ の方向へ移動したとしても, $\boldsymbol{p}_{k}^{t}$ 自体が個体群 の最良探索点 $\boldsymbol{p}_{g}^{t}$ に近づいてきているため, $\boldsymbol{p}_{g}^{t}$ 付近の局所探索 能力の低下を招くことなく, 個体の $\boldsymbol{p}_{g}^{t}$ への過度な集中を緩和 することができると考えられる。

4.3.2 現在の探索点でその個体の最良探索点が更新された 場合

次に, 個体 $i$ の現在の探索点 $\boldsymbol{x}_{i}^{t}$ がその個体の最良探索点 $\boldsymbol{p}_{i}^{t}$ である場合, 現在の探索点 $\boldsymbol{x}_{i}^{t}$ および現在の探索点への方向 $\boldsymbol{v}_{i}^{t}$ はその個体の最良探索点 $\boldsymbol{p}_{i}^{t}$ が更新されていることから有望であ ると考えられ, 現在の探索点 $\boldsymbol{x}_{i}^{t}$ 付近およびその方向にさらに 良い点がある可能性がある. しかし, 従来の探索方向の更新式 （5）では，常に個体群の最良探索点 $\boldsymbol{p}_{g}^{t}$ への方向を含んでいる ため，次の探索方向 $\boldsymbol{v}_{i}^{t+1}$ に現在の個体の状況が十分に反映さ れず, Fig. 8 のように, 個体群の最良探索点 $\boldsymbol{p}_{g}^{t}$ へ集中しやす くなるという問題点がある. そこで, このような場合には, 個 体 $i$ の次の探索方向 $\boldsymbol{v}_{i}^{t+1}$ を次の式（12）により決定するよう に変更する (Fig. 9).

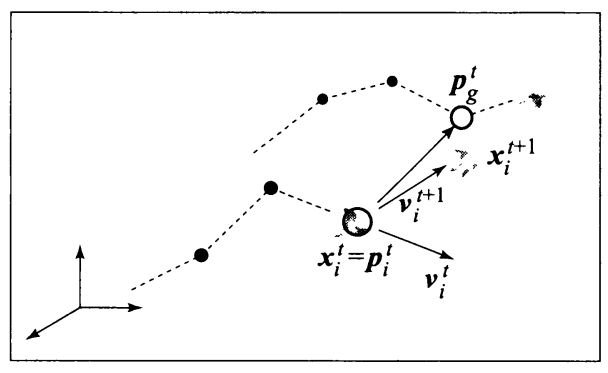

Fig. 8 The search direction when the best search point of an individual is renewed at the current search point

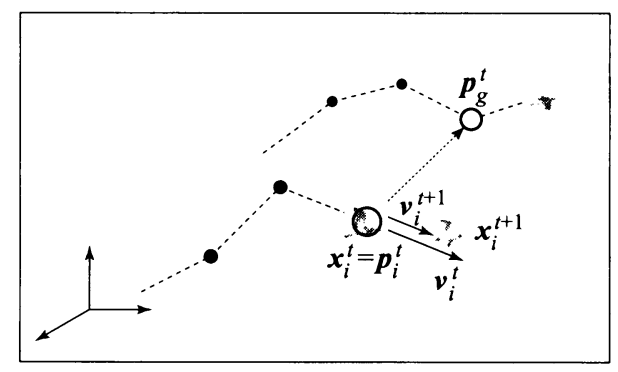

Fig. 9 The new search direction when the best search point of an individual is renewed at the current search point

$$
\boldsymbol{v}_{i}^{t+1}=\omega^{t} \boldsymbol{v}_{i}^{t}
$$

これにより，個体の $\boldsymbol{p}_{g}^{t}$ への集中を緩和するとともに，その 個体の最良探索点の方向 $\boldsymbol{v}_{i}^{t}$ に移動しながら現在の最良探索点 $\boldsymbol{p}_{i}^{t}$ 周辺を探索することができる.

\subsection{3 その他の場合}

個体の状況が上記以外の場合は, 従来の PSO 手法と同じ探 索方向と探索点の更新式 (5)，（6）を用いる.

このような個体の状況に応じた移動の採用により，個体の局 所への過度の集中を緩和し，探索における個体の多様化を図る。

\section{4 離脱行動}

PSO 手法では, Fig.10のように，探索が進むにつれて個体 は次第に個体群の最良探索点付近に集中していくため広域な探 索が難しくなる。 そこで, 探索の広域化を眓るために, ある確 率で次のような離脱的な行動をとるものとする：実行可能領域 内でランダムに移動する (Secession I)，実行可能領域の境界に ランダムに移動する（Secession II），ある座標軸方向にランダ ムに移動する（Secession III）。

1. 実行可能領域内にランダムに移動 個体が個体群の最良探索 点付近に集中したと判断されたら，個体を実行可能領域内 にランダムに移動させる。

2. 実行可能領域の境界にランダムに移動 個体が個体群の最 良探索点付近に集中したと判断されたら, 初期個体群の 生成で用いた超立方体の变数の上限値 $(1)$, 下限值 $(-1)$ のどちらかを適当にとり，現在の基点解を用いた準同型写 像オペレータによって個体を境界に移動させる。

3. ある座標軸方向にランダムに移動 個体が個体群の最良探索 点付近に集中したと判断されたら，個体をランダムに選択 された座標軸方向に移動させる.

これらの離脱行動の例を Fig. 11 に示す. 


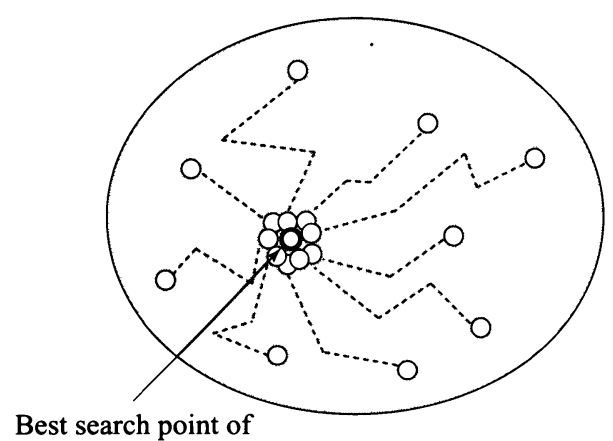

the population

Fig. 10 The concentration of individuals around the best search point of the population

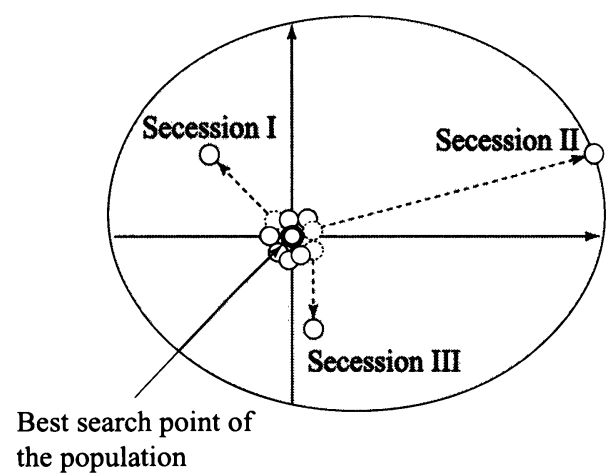

Fig. 11 The secession

\section{5 多重ストレッチング技法}

PSO 手法では探索が進み, 個体群が群れの最良の探索点付近 に集まってくると, 群れの最良点が長期にわたって更新されな いことがしばしばある。この点が大域的最適解であればよいが, そうでない場合，この点（局所解）から抜け出す必要がある.

Parsopoulos ら [9] は, PSO 手法における個体の局所解への 停留を抑制するために，現在得られている局所解の情報を用い て, 個体の評価関数 (目的関数) $f(\boldsymbol{x})$ を別の評価関数 $H(\boldsymbol{x})$ に 変更することにより，現在の局所解を抜け出し，探索の広域化 を目指すというストレッチング技法を提案した。しかし，この ストレッチング技法により，現在の局所解から抜け出すことが できるが，次に得られた別の局所解に対してストレッチングを 適用すると以前の局所解に再び陥る可能性がある，そこで, 本 研究では, 複数の局所解に対応した多重ストレッチング技法を 提案する．具体的には， $Q$ 個の局所解 $\overline{\boldsymbol{x}}_{q}, q=1, \ldots, Q$ に対し て次のような関数を考える.

$$
\begin{aligned}
G_{q}(\boldsymbol{x})= & f(\boldsymbol{x})+\gamma_{1}\left\|\boldsymbol{x}-\overline{\boldsymbol{x}}_{q}\right\| \\
& \times\left(\operatorname{sign}\left(f(\boldsymbol{x})-f\left(\overline{\boldsymbol{x}}_{\min }\right)\right)+1\right) \\
H_{q}(\boldsymbol{x})= & G_{q}(\boldsymbol{x}) \\
& +\gamma_{2} \frac{\operatorname{sign}\left(f(\boldsymbol{x})-f\left(\overline{\boldsymbol{x}}_{\mathrm{min}}\right)\right)+1}{\tanh \left(\mu\left(G_{q}(\boldsymbol{x})-G_{q}\left(\overline{\boldsymbol{x}}_{q}\right)\right)\right)} \\
& S(\boldsymbol{x})=\sum_{q=1}^{Q} H_{q}(\boldsymbol{x}) / Q
\end{aligned}
$$

ここで, $\overline{\boldsymbol{x}}_{\min }$ は $Q$ 個の局所解の中で最も良い評価值を与える 局所解であり， $\gamma_{1}, \gamma_{2}, \mu$ はパラメー夕である。また $\operatorname{sign}(\cdot)$ は 次のように定義される関数である.

$$
\operatorname{sign}(x)=\left\{\begin{array}{cc}
1, & x>0 \\
0, & x=0 \\
-1, & x<0
\end{array}\right.
$$

式（15）で表される評価関数 $S(\boldsymbol{x})$ は, 最も良い局所解での 元の評価関数值 $f\left(\overline{\boldsymbol{x}}_{\min }\right)$ より小さな值をとる探索点 $\overline{\boldsymbol{x}}$ に対し ては元の評価関数值 $f(\boldsymbol{x})$ と等しい値, 各局所解付近の探索点 に対しては極端に大きな值, これら以外の探索点に対しては元 の評価值 $f(\boldsymbol{x})$ に局所解からの距離に応じたペナルティが付加 された值を与える関数である。このように, 複数の局所解を同 時に考慮した $S(\boldsymbol{x})$ を新たな評価関数とすることにより, 以前 に得られた局所解に再び陥ることなく，これまでの局所解より も良い解が存在する領域を探索することが可能になる.

\section{6 改良型 PSO 手法の手順}

手順 1 制約違反に基づく目的関数を最大化する問題を従来の 基本的な PSO 手法で解き，実行可能解を一つ求め, 準同 型写像の基点解 $\boldsymbol{r}$ とする. また, 最大世代数 $G_{\max }$ を設定 し，探索回数カウン夕 $t$ を 0 とする.

手順 2 準同型写像を用いて実行可能性が保証された初期の探 索点を生成する. 具体的には，手順 1 で求めた基点解 $\boldsymbol{r}$ を 用いた準同型写像により超立方体内にランダムに生成した $I$ 個の点を決定変数空間の実行可能領域内の点に写像し，そ れらの点を個体の初期探索点 $\boldsymbol{x}_{i}^{0}, i=1, \ldots, I$ とする。 ま た, 各個体の初期探索点 $\boldsymbol{x}_{i}^{0}$ を初期のその個体の最良探索 点 $\boldsymbol{p}_{i}^{0}$ とし, 初期探索点 $\boldsymbol{x}_{i}^{0}, i=1, \ldots, I$ の中で最良のも のを初期の個体群の最良探索点 $\boldsymbol{p}_{g}^{0}$ とする.

手順 3 各個体はその個体の最良探索点 $\boldsymbol{p}_{i}^{t}$ と個体群の最良探 索点 $\boldsymbol{p}_{g}^{t}$ を用いて，個体の状況に合わせた移動式により，次 の探索点 $\boldsymbol{x}_{i}^{t+1}$ への方向 $\boldsymbol{v}_{i}^{t+1}$ を決定後, 式 (6) により個 体は現在の探索点から次の探索点へ移動する.

手順 42 分法による実行可能性の修正を行う個体に対しては, 移動後の個体の探索点 $\boldsymbol{x}_{i}^{t+1}$ が実行可能かどうかを調べ, もし実行可能でなければ，2 分法により実行可能となるよ うに修正する。

手順 5 多重ストレッチング技法を適用するかどうかを判定す る。適用するならば手順 6 へ行き, 適用しないならば手順 7 へ行く.

手順 6 目的関数 $f(\cdot)$ を变換した評価関数 $S(\cdot)$ により, 手順 3 による個体の移動後の探索点 $\boldsymbol{x}_{i}^{t+1}, i=1, \ldots, I$ での評 価を行う. 手順 8 へ行く.

手順 7 手順 3 による個体の移動後の探索点 $\boldsymbol{x}_{i}^{t+1}, i=1, \ldots, I$ での目的関数值 $f\left(\boldsymbol{x}_{i}^{t+1}\right)$ で評価する.

手順 8 手順 6 または 7 で求めた評価值がその個体の最良探索 点 $\boldsymbol{p}_{i}^{t}$ での評価值より良ければ, $\boldsymbol{p}_{i}^{t+1}:=\boldsymbol{x}_{i}^{t+1}$ として, その 個体の最良探索点を更新する。 そうでなければ, $\boldsymbol{p}_{i}^{t+1}:=\boldsymbol{p}_{i}^{t}$ とする.

手順 $9 \boldsymbol{p}_{i}, i=1,2, \ldots, I$ の中で最良の点を $\boldsymbol{p}_{\text {best }}^{\boldsymbol{t}+1}$ とする. もし $\boldsymbol{p}_{\text {best }}^{t+1}$ での評価值が $\boldsymbol{p}_{g}^{t}$ での評価値より良ければ, 
$\boldsymbol{p}_{g}^{t+1}:=\boldsymbol{p}_{\text {best }}^{t+1}$ として, 個体群の最良探索点を更新する. そうでなければ, $\boldsymbol{p}_{g}^{t+1}:=\boldsymbol{p}_{g}^{t}$ とする.

手順 10 各個体に対して, 離脱行動の条件を満たしていれば, ある確率で離脱行動を適用する。

手順 $11 t=T_{\max }$ (最大探索回数) となれば終了. そうでな ければ, $t:=t+1$ として, 手順 3 に戻る.

ここで, 終了条件は, 探索回数 $t$ が最大探索回数 $T_{\max }$ に達す ることである。 また, 個体 $i$ に対する多重ストレッチング技法 の適用条件は, 個体 $i$ の最良探索点がある定数回更新されない こととする.

\section{5. 数 值 実 験}

本研究では, 文献 $[2]$ と同様の 5 リンク 4 関節 $(N=5)$ のシリアルリンクロボットを用いて数值実験を行う. 実験に おいて, シリアルリンクロボットのパラメータは, $\tau_{1, \min }=$ $\tau_{2, \min }=\tau_{3, \min }=\tau_{4, \min }=-2,000[\mathrm{Nmm}], \tau_{1, \max }=$ $\tau_{2, \max }=\tau_{3, \max }=\tau_{4, \max }=2,000[\mathrm{Nmm}], l_{1}=l_{5}=60[\mathrm{~mm}]$, $l_{2}=l_{4}=75[\mathrm{~mm}], l_{3}=123[\mathrm{~mm}], m_{1}=m_{5}=25[\mathrm{~g}], m_{2}=$ $m_{4}=75[\mathrm{~g}], \quad m_{3}=140[\mathrm{~g}], \quad I_{1}=I_{5}=9.8\left[\mathrm{kgmm}^{2}\right], \quad I_{2}=$ $I_{4}=54\left[\mathrm{kgmm}^{2}\right], \quad I_{3}=230\left[\mathrm{kgmm}^{2}\right], \omega_{\max }=31.4[\mathrm{rad} / \mathrm{s}]$, $T=1.5[\mathrm{~s}]$ とする. 一方, 改良型 PSO 手法のパラメー夕は, 個体数 $I=40$, 世代数 $G_{\max }=100$ とする. このような設定 の下で, 改良型 PSO 手法を跳躍高最大化問題に適用し, 最終 的に得られた近似最適解（駆動トルク波形）を Fig. 12〜15に 示す. また, 文献 [2] において提案されている GA に基づく解 法を, 試行錯誤的に定められたパラメー夕值, 個体数 200 , 世 代数 100 , トーナメント選択, 交叉確率 0.7 , 突然変異率 0.04 を用いて適用し, 最終的に得られた探索における世代数と跳躍 高の関係を Fig. 16 に示すとともに, 改良型 PSO 手法による 探索における世代数と跳躍高の関係を Fig. 17 に示す.

文献 [2] の遺伝的アルゴリズムに基づく解法を適用し, 最終 的に得られた最良跳躍高は $h_{\max }=615[\mathrm{~mm}]$ であるが, 本研

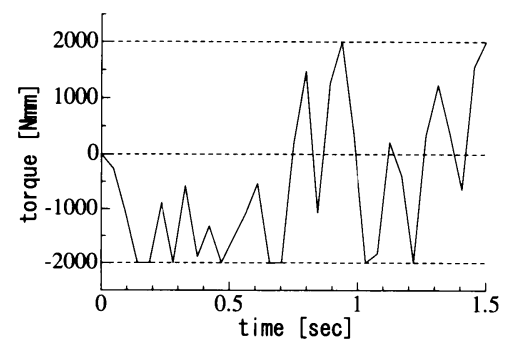

Fig. 12 Torque pattern of the first joint obtained by PSO

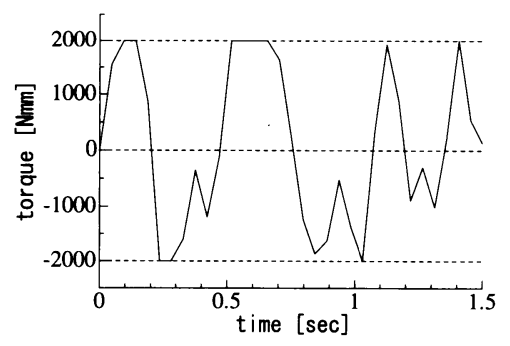

Fig. 13 Torque pattern of the second joint obtained by PSO
究で提案する改良型 PSO 手法に基づく解法を用いた場合, 最 良跳躍高は $h_{\max }=729[\mathrm{~mm}]$ であり, 求解の正確さに関して, 改良型 PSO 手法に基づく解法は遺伝的アルゴリズムに基づく 解法より優れていることが分かる. また, Fig. 18 から遺伝的

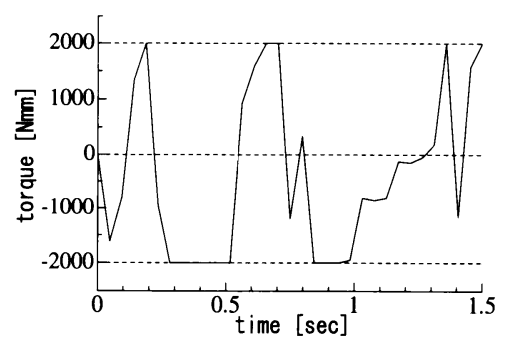

Fig. 14 Torque pattern of the third joint obtained by PSO

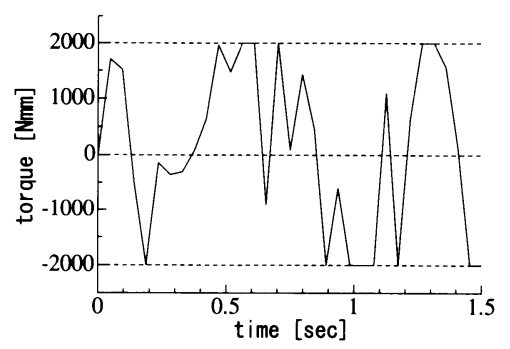

Fig. 15 Torque pattern of the forth joint obtained by PSO

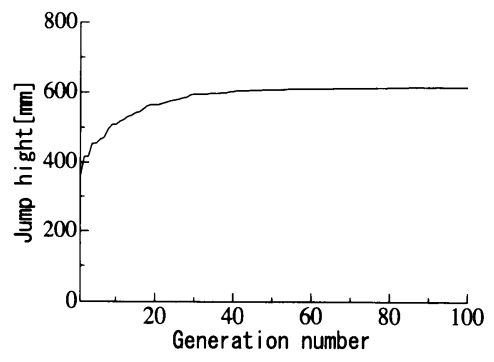

Fig. 16 Search process of GA

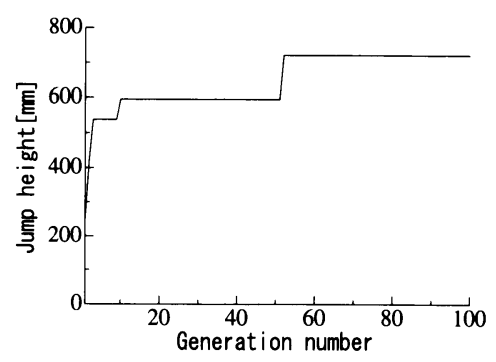

Fig. 17 Search process of PSO

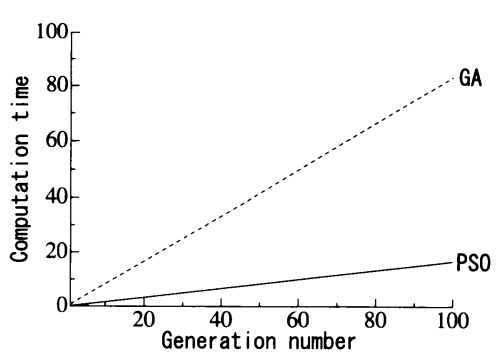

Fig. 18 Comparison of computation time of GA and PSO 
アルゴリズムに基づく解法を用いた場合，計算時間に約 83 時間 必要であるが，改良型 PSO 手法に基づく解法では約 17 時間で より速く跳躍高が大きくなる駆動トルク波形を得ており, 求解 の速さに関しても優れている。これらのことから, 跳躍高最大 化問題に対する近似解法として, 改良型 PSO 手法に基づく解 法は遺伝的アルゴリズムに基づく解法より有望であるといえる。

\section{6. おわりに}

本研究では, 回転型モー夕を用いたシリアルリンクロボット の跳躍高最大化問題に焦点を当て, 求解の高速化および高精度 化のために, 跳躍高最大化問題に対するWalsh 級数を用いた解 表現と改良型 PSO 手法に基づく解法を提案した. さらに, 数 值実験を通して, 提案した手法の有用性を示した。

謝 辞 本研究は, 広島大学 21 世紀 $\mathrm{COE}$ プログラム「超 速ハイパーヒューマン技術が開く新世界—21 世紀産業革命に向 けて一」および文部科学省科学研究費 基盤研究 (C) 18510127 の助成を受けている。

\section{参 考 文 献}

[1] 美多勉：非線形制御入門一劣駆動ロボットの技能制御論—. 昭晃堂,
2000 .

[2] 東森充, 原田学, 石井抱, 金子真：“シリアルリンクロボットの跳躍 パターン生成”, 日本ロボット学会誌, vol.23, no.8, pp.1002-1010, 2005.

[ 3 ] J. Morimoto and K. Doya: "Reinforcement learning of dynamic motor sequence: Learning to stand up," Proceedings of IEEE/RSJ International Conference on Intelligent Robots and Systems, vol.3, pp.1721-1726, 1998.

[4] 森本淳, 銅谷賢治：“階層型強化学習を用いた実ロボットによる起立 運動の獲得”, 第 5 回ロボティクスシンポジア予稿集, pp.397-402, 2000.

[5] 有本卓: 信号・画像のディジタル処理. 産業図書, 1975.

[6] J. Kennedy and R.C. Eberhart: "Particle swarm optimization," Proceedings of IEEE International Conference on Neural Networks, pp.1942-1948, 1995.

[ 7 ] T. Matsui, K. Kato, M. Sakawa, T. Uno and K. Morihara: "Particle swarm optimization based heuristics for nonlinear programming problems," Proceedings of International MultiConference of Engineers and Computer Scientists 2007, pp.2312-2317, 2007.

[ 8 ] S. Koziel and Z. Michalewicz: "Evolutionary algorithms, homomorphous mappings, and constrained parameter optimization," Evolutionary Computation, vol.7, no.1, pp.19-44, 1999.

[9] K.E. Parsopoulos and M.N. Varahatis: "Recent approaches to global optimization problems through particle swarm optimization," Natural Computing, vol.1, no.2-3, pp.235-306, 2002.

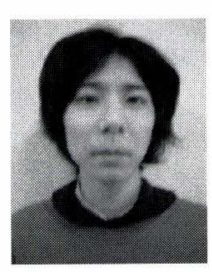

松井 猛 (Takeshi Matsui)

2002 年広島県立大学経営学部卒業. 2005 年同大学 大学院経営情報学研究科修士課程修了. 2005 年広 島大学大学院工学研究科博士課程後期入学. 現在, ソフトコンピューティング手法に基づく非線形計画 法の研究に従事。（日本ロボット学会学生会員）

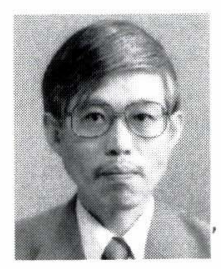

坂和正敏 (Masatoshi Sakawa)

1970 年京都大学工学部数理学科卒業, 1975 年同大 学大学院博士課程修了. 1975 年神戸大学工学部シ ステム助手, 1981 年同大学助教授, 1987 年岩手大 学工学部教授を経て, 1990 年広島大学工学部第二 類 (電気系) 計数管理工学講座教授, 2001 年同大 学大学院工学研究科複雑システム工学専攻教授とな り現在に至る. 大規模システム, 多目的システム, ファジィシステ ムに打ける意思決定手法とその応用に関する研究に従事. 工学博士. 著書: 線形システムの最適化, 非線形システムの最適化, ファジィ理 論の基礎と応用, 経営数理システムの基礎 (森北出版), ソフト最適 化, 遺伝的アルゴリズム (朝倉書店), Fuzzy Sets and Interactive Multiobjective Optimization (Plenum Press) 等.

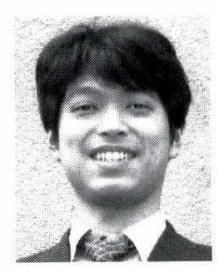

東森 充 (Mitsuru Higashimori)

1998 年広島大学大学院工学研究科博士課程前期修 了. 同年株式会社東芝入社. 2002 年 8 月広島大学大 学院工学研究科助手, 2006 年大阪大学大学院工学研 究科助手となり, 現在に至る。ロボットハンド, ア クティブセンシングなどの研究に興味を持つ. 2003 年度計測自動制御学会学術奨励賞研究奨励賞受賞. 計測自動制御学会, 日本機械学会の会員.（日本ロボット学会正会員）

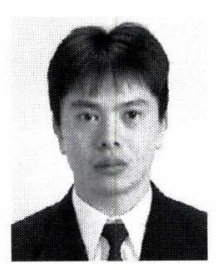

加藤浩介（Kosuke Kato）

1991 年大阪大学基礎工学部生物学科卒業. 1993 年 同大学大学院博士課程前期修了. 1994 年同課程後 期退学. 1994 年広島大学工学部第二類 (電気系) 計数管理工学講座助手, 2001 年同大学大学院工学 研究科複雑システム工学専攻助手, 2002 年同大学 大学院工学研究科複雑システム工学専攻助教授とな り，現在に至る。ソフトコンピューティング手法のシステム最適化へ の応用に関する研究に従事.

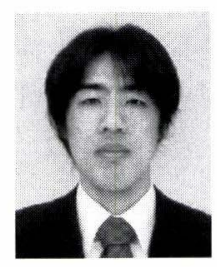

宇野剛史（Takeshi Uno）

1998 年大阪大学工学部応用物理学科卒業. 2003 年 同大学大学院工学研究科博士課程後期修了. 2003 年年広島大学大学院工学研究科複雑システム工学専 攻助手となり現在に至る。博士 (工学). 主に競合 環境下での施設配置問題における最適化とその応用 に関する研究に従事. 電子情報通信学会, システム 制御情報学会, 日本知能情報ファジィ学会, 日本オペレーションズ. リサーチ学会の会員.

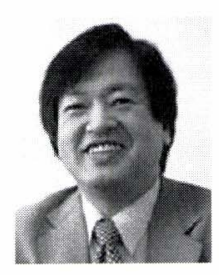

\section{金子 真 (Makoto Kaneko)}

1981 年東京大学工学系研究科博士課程卒業. 工学 博士. 通産省工業技術院機械技術研究所, 九州工業 大学助教授, 広島大学教授を経て, 2006 年より大 阪大学教授, アクティブセンシングや把握戦略の研 究に興味を持つ。日本機械学会奨励賞 (1983), 日 本ロボット学会論文賞 (1994), 計測自動制御学会 論文賞 (1996, 2002), Humboldt Research Award (1997), IEEE ICRA The Best Manipulation Paper Award (2000), IEEE ISATP The Outstanding Paper Award (2001), IEEE RAS King-Sun Fu Memorial Best Transactions Paper Award (2003), 日本コンピュー 夕外科学会講演論文賞最優秀賞 (2004), IEEE ICIA The Best Conference Paper Award（2005）を受賞.（日本ロボット学会正会員） 